Economics Development Analysis Journal

\title{
Analisis Makro Ekonomi Sebelum dan Sesudah Penerapan Redenominasi Mata Uang
}

\author{
Maria Febrida $^{1 \bowtie}$, Lesta Karolina Br. Sebayang ${ }^{2}$
}

Jurusan Ekonomi Pembangunan, Fakultas Ekonomi, Universitas Negeri Semarang

\begin{tabular}{l} 
Info Artikel \\
\hline Sejarah Artikel: \\
Diterima Januari 2016 \\
Disetujui Maret 2016 \\
Dipublikasikan Mei 2016 \\
\hline Keywords: \\
Currency Redenomination; \\
Macroekonomic, Money
\end{tabular}

\begin{abstract}
Abstrak
Rencana redenominasi rupiah di Indonesia menjadikan pengalaman beberapa negara yang telah menerapkan redenominasi mata uang penting untuk ditinjau dari sisi makro ekonomi saat sebelum dan sesudah redenominasi sehingga menjadi dasar pertimbangan bagi Indonesia mengambil keputusan dalam rencana penerapan redenominasi rupiah. Tujuan penelitian ini untuk mengetahui ada tidaknya perbedaan kondisi inflasi, nilai tukar, ekspor, penanaman modal asing (PMA) dan pertumbuhan ekonomi 1 tahun sebelum dan 1 tahun sesudah menerapkan redenominasi pada 20 negara yang telah menerapkan redenominasi. Penelitian ini menggunakan metode penelitian kuantitatif dengan alat analisis uji beda dua rata-rata sampel berpasangan. Hasil analisis menunjukkan bahwa pada variabel nilai tukar terdapat perbedaan antara sebelum dan sesudah redenominasi yaitu nilai tukar semakin lemah setelah penerapan redenominasi, sedangkan pada variabel inflasi, ekspor, PMA, dan pertumbuhan ekonomi tidak terdapat perbedaan sebelum dan sesudah redenominasi.
\end{abstract}

\begin{abstract}
Rupiah redenomination which planned by Indonesia make the experience of countries that have implemented the currency redenomination is important to be reviewed in terms of macroeconomic before and after the redenomination so that it becomes a basic consideration for Indonesia to take decisions in the plan of implementation rupiah redenomination. The purpose of this study is to determine whether there is difference in the conditions of inflation, exchange rate, exports, foreign direct investment (FDI) and economic growth in the current 1 year before and 1 year after implementing the redenomination in the 20 countries that have implemented the currency redenomination. This study used a quantitative method, with analysis dependent sample t-test which showed that there is a difference between before and after redenomination in exchange rate variable is getting weaker after the implementation of the redenomination, while there is no difference before and after the redenomination in inflation, exports, FDI, and economic growth.
\end{abstract}

(C) 2016 Universitas Negeri Semarang

Alamat korespondensi:

Ruang Jurnal Gedung L FE UNNES, Sekaran Gunungpati

Semarang, 50229, Indonesia

E-mail: febridamaria@yahoo.co.id 


\section{PENDAHULUAN}

Rencana redenominasi rupiah di Indonesia pertama kali dilontarkan oleh Gubernur Bank Indonesia pada tanggal 3 Agustus 2010 yang pada saat itu dijabat oleh Darmin Nasution. Rencana redenominasi rupiah akan menghilangkan tiga angka nol pada nominal uang, barang, maupun upah tanpa mengubah nilai riil rupiah, dengan tujuan untuk penyederhanaan mata uang, efisiensi dalam pencatatan data keuangan, menciptakan kesetaraan ekonomi Indonesia dengan regional serta meningkatkan martabat rupiah.

Pecahan mata uang yang terlalu besar dinilai kurang efisien dalam proses pembayaran dan pencatatan transaksi keuangan. Uang pecahan Indonesia yang terbesar saat ini adalah Rp 100.000,- merupakan pecahan terbesar kedua di dunia setelah Dong yaitu mata uang Vietnam yang mencetak đ500.000.

Pengalaman beberapa negara yang telah menerapkan redenominasi mata uang dibutuhkan sebagai gambaran bagi Indonesia dalam mempersiapkan rencana redenominasi rupiah.

Beberapa contoh negara sukses melaksanakan kebijakan redenominasi adalah Turki, Polandia dan Romania. Sementara itu, negara-negara seperti Argentina, Brasil dan Rusia tercatat sebagai negara yang gagal dalam melakukan redenominasi mata uang.

Kegagalan ini dinilai karena kebijakan redenominasi dilaksanakan ketika terjadi pelemahan dan ekonomi tak siap serta kekurangan pemerintah Brasil dan Argentina yang tidak mampu mengelola inflasi yang sangat tinggi saat menerapkan redenominasi. Sedangkan kegagalan di Rusia dinilai karena pemerintah gagal mengelola obligasi yang terus menggunung serta ketidakpercayaan masyarakat Rusia kepada pemerintahnya dan menganggap pemerintah Rusia tengah "membodohi" masyarakat.

Sejak tahun 1923, setidaknya sudah 50 negara yang telah melakukan redenominasi. Tingkat inflasi yang tinggi merupakan faktor utama (most dominant driving factor) yang mendorong suatu negara memutuskan untuk melakukan redenominasi mata uang (Suhendra dan Handayani, 2012:21). Berbeda dengan hal tersebut, rencana redenominasi di Indonesia justru dilakukan bukan karena Indonesia sedang mengalami hiperinflasi namun semata-mata untuk penyederhanaan nominal mata uang. Jika suatu negara mengalami hiperinflasi, pemerintah akan sulit dalam mendapatkan kepercayaan dari pasar domestik dan internasional yang juga akan berdampak penurunan pada penanaman modal asing (PMA). Seperti yang terjadi di Cina, hiperinflasi Cina didorong oleh upaya pemerintah untuk pendapatan (Zhao \& Li, 2015).

Mengingat salah satu tujuan adanya rencana redenominasi rupiah di Indonesia adalah untuk meningkatkan martabat rupiah atau dengan kata lain meningkatkan kepercayaan pasar luar negeri terhadap mata uang rupiah, maka indikator PMA dari negara-negara yang sudah melakukan redenominasi menjadi salah satu variabel yang dianalisis perbedaannya saat sebelum dan sesudah penerapan redenominasi karena tingkat penanaman modal asing disuatu negara dapat menggambarkan tingkat kepercayaan negara asing terhadap negara tersebut dalam berinvestasi atau menanamkan modal. Tabel 1 menunjukkan PMA sebelum dan sesudah redenominasi dari 20 negara yang sudah menerapkan redenominasi mata uang. 
Tabel 1. Perbandingan Penanaman Modal Asing Sebelum dan Sesudah Redenominasi di Negara yang Sudah Menerapkan Redenominasi Mata Uang

\begin{tabular}{lrrr}
\hline \multicolumn{1}{c}{ Negara } & Tahun & \multicolumn{2}{c}{ Penanaman Modal Asing (US\$) } \\
& Redenominasi & $\begin{array}{r}\text { 1 Tahun Sebelum } \\
\text { Redenominasi }\end{array}$ & \multicolumn{1}{c}{ Redenominasi } \\
\hline Israel & 1985 & $89,500,000$ & $35,800,000$ \\
Bolivia & 1987 & $20,000,000$ & $-10,100,000$ \\
Peru & 1991 & $41,000,000$ & $-79,000,000$ \\
Argentina & 1992 & $2,439,000,000$ & $2,793,085,410$ \\
Sudan & 1992 & $-620,000$ & $-160,000$ \\
Mexico & 1993 & $4,393,000,000$ & $10,972,500,000$ \\
Uruguay & 1993 & $11,300,000$ & $154,500,000$ \\
Brazil & 1994 & $1,292,000,000$ & $4,859,000,000$ \\
Poland & 1995 & $1,875,000,000$ & $4,498,000,000$ \\
Ukraine & 1996 & $267,000,000$ & $623,000,000$ \\
Dem.Rep.Of Congo & 1998 & $-44,350,000$ & $11,160,000$ \\
Rusia & 1998 & $4,864,643,273$ & $3,309,430,000$ \\
Angola & 1999 & $1,113,970,000$ & $878,620,000$ \\
Bulgaria & 1999 & $537,317,256$ & $1,001,503,842$ \\
Belarus & 2000 & $444,000,000$ & $95,800,000$ \\
Romania & 2005 & $6,443,000,000$ & $11,450,830,000$ \\
Turkey & 2005 & $2,785,000,000$ & $20,185,000,000$ \\
Azerbaijan & 2006 & $4,476,396,000$ & $4,594,234,000$ \\
Mozambique & 2006 & $122,413,756$ & $416,689,348$ \\
Ghana & 2007 & $636,010,000$ & $2,714,916,344$ \\
\hline Sun & & & \\
\hline
\end{tabular}

Sumber: World Bank

Pada Tabel 1 beberapa negara seperti Turki, Romania, Bulgaria dan Mexico mengalami peningkatan PMA yang sangat drastis di negaranya setelah 1 tahun menerapkan redenominasi mata uang, artinya setelah menerapkan redenominasi, pasar luar negeri semakin percaya untuk berinvestasi atau menanamkan modalnya di Turki, Romania, Bulgaria dan Mexico. Beberapa negara justru sebaliknya seperti yang dialami oleh Rusia dan Angola, PMA menurun drastis setelah 1 tahun menerapkan redenominasi yang artinya kepercayaan terhadap mata uang Rusia dan Angola menurun sehingga minat pasar luar negeri untuk menamankan modalnya di Rusia dan Angola juga menjadi berkurang.

Variabel makro ekonomi lain yang perlu dianalisis selain penanaman modal asing adalah inflasi, nilai tukar, ekspor dan pertumbuhan ekonomi. Dalam model perekonomian tertutup atau terbuka dengan pasar lengkap, menargetkan inflasi inti memungkinkan kebijakan moneter untuk memaksimalkan kesejahteraan dengan mereplikasi keseimbangan harga yang fleksibel (Prasad \& Zhang, 2015). Tingkat ekspor suatu negara dapat menunjukkan kemampuan produk negara tersebut dapat bersaing di pasar internasional, maka perlu ditinjau untuk melihat 
adakah perbedaan sebelum dan sesudah redenominasi. Untuk membuat sukses redenominasi hal yang paling penting adalah tingkat inflasi yang rendah, pertumbuhan ekonomi yang stabil, jaminan stabilitas harga dan sosialisasi yang baik kepada masyarakat (Lianto \& Suryaputra, 2015). Adapun dampak positif yang diharapkan dari rencana kebijakan redenominasi rupiah ini adalah kesejahteraan masyarakat sehingga pada negara yang sudah menerapkan redenominasi perlu ditinjau perbedaan pertumbuhan ekonomi sebelum dan sesudah negara tersebut menerapkan kebijakan redenominasi pada mata uangnya. Tabel 2 menunjukkan tingkat inflasi dan pertumbuhan ekonomi sebelum dan sesudah redenominasi dari 20 negara yang telah menerapkan redenominasi mata uang.

Tabel 2. Perbandingan Tingkat Inflasi dan Pertumbuhan Ekonomi Negara-Negara yang Telah Menerapkan Redenominasi

\begin{tabular}{|c|c|c|c|c|c|}
\hline \multirow{2}{*}{ Negara } & \multirow{2}{*}{$\begin{array}{c}\text { Tahun } \\
\text { Redenomi } \\
\text { nasi }\end{array}$} & \multicolumn{2}{|c|}{$\begin{array}{c}1 \text { Tahun sebelum } \\
\text { Redenominasi }\end{array}$} & \multicolumn{2}{|c|}{$\begin{array}{l}1 \text { Tahun setelah } \\
\text { Redenominasi }\end{array}$} \\
\hline & & $\begin{array}{l}\text { Inflasi } \\
(\%)\end{array}$ & $\begin{array}{l}\text { Pertumbuhan } \\
\text { Ekonomi (\%) }\end{array}$ & $\begin{array}{l}\text { Inflasi } \\
(\%)\end{array}$ & $\begin{array}{l}\text { Pertumbuhan } \\
\text { Ekonomi (\%) }\end{array}$ \\
\hline Israel & 1985 & 373.8 & 0.9 & 48.2 & 4.8 \\
\hline Bolivia & 1987 & 276.3 & -2.6 & 16.0 & 2.9 \\
\hline Peru & 1991 & $7,481.7$ & -5.0 & 73.5 & -0.5 \\
\hline Argentina & 1992 & 171.70 & 12.7 & 10.60 & 5.9 \\
\hline Sudan & 1992 & 123.6 & 7.5 & 101.4 & 4.6 \\
\hline Mexico & 1993 & 15.5 & 3.6 & 7.0 & 4.7 \\
\hline Uruguay & 1993 & 68.5 & 7.9 & 44.7 & 7.3 \\
\hline Brazil & 1994 & $1,928.0$ & 4.7 & 66.0 & 4.4 \\
\hline Poland & 1995 & 33.3 & 5.3 & 19.8 & 6.2 \\
\hline Ukraine & 1996 & 376.7 & -12.2 & 15.9 & -3.0 \\
\hline Dem.Rep.Of Congo & 1998 & 198.5 & -5.6 & 284.9 & -4.3 \\
\hline Rusia & 1998 & 14.8 & 1.4 & 85.7 & 6.4 \\
\hline Angola & 1999 & 107.3 & 6.8 & 325.0 & 3.0 \\
\hline Bulgaria & 1999 & 18.7 & 3.5 & 10.3 & 6.0 \\
\hline Belarus & 2000 & 293.7 & 3.4 & 61.1 & 4.7 \\
\hline Romania & 2005 & 11.9 & 9.1 & 6.6 & 8.7 \\
\hline Turkey & 2005 & 10.6 & 9.4 & 9.6 & 6.9 \\
\hline Azerbaijan & 2006 & 9.7 & 26.4 & 16.6 & 25.0 \\
\hline Mozambique & 2006 & 7.2 & 8.7 & 8.2 & 7.3 \\
\hline Ghana & 2007 & 10.9 & 6.4 & 16.5 & 8.4 \\
\hline
\end{tabular}

Sumber: World Bank

Pada Tabel 2, beberapa negara seperti Polandia, Ukraine, Rumania dan Turki mengalami penurunan inflasi pasca 1 tahun redenominasi. Disisi lain negara seperti Congo,
Rusia, Angola justru mengalami inflasi yang melonjak tinggi pasca 1 tahun dilakukannya redenominasi. Walau Rumania dan Turkey mengalami penurunan inflasi, pertumbuhan 
ekonomi juga menurun setelah 1 tahun menerapkan redenominasi. Beberapa negara lainnya juga mengalami penurunan pertumbuhan ekonomi yang sangat drastis seperti yang dialami Argentina dan Sudan. Sedangkan peningkatan pertumbuhan ekonomi pasca 1 tahun redenominasi dialami oleh negara Israel, Bolivia, Peru, Mexico, Rusia, Bulgaria, Belarus, dan Ghana.

\section{METODE PENELITIAN}

Jenis data yang digunakan dalam penelitian ini adalah data kuantitatif. Sumber yang digunakan adalah data sekunder berupa data makro ekonomi yaitu tingkat inflasi, nilai tukar, penanaman modal asing, ekspor dan pertumbuhan ekonomi 1 tahun sebelum redenominasi dan 1 tahun setelah redenominasi dari 20 negara yang telah menerapkan redenominasi mata uang. yang diperoleh dari publikasi World Bank yaitu dari situs data.worldbank.org.

Populasi penelitian ini adalah negaranegara yang telah melakukan redenominasi sejak tahun 1943 hingga tahun 2008 sebanyak 52 negara. Pengambilan sampel menggunakan metode purposive sampling untuk memperoleh sampel yang memenuhi kriteria tertentu yaitu terpenuhinya kebutuhan data dari variabel makroekonomi dalam penelitian ini yang mencakup inflasi, nilai tukar, ekspor, penanaman modal asing, serta pertumbuhan ekonomi dan keseluruhan maupun sebagian variabel makroekonomi yang diteliti dari negara-negara sampel memiliki kemiripan dengan Indonesia. Dari 52 populasi diambil sebanyak 20 negara sebagai sampel yang memenuhi persyaratan dan dianggap telah representatif untuk dilakukan uji beda, daftar 20 negara sampel seperti pada Tabel 1 dan 2.

Metode penelitian yang digunakan dalam penelitian ini adalah metode deskriptif dan komparatif. Metode deskriptif digunakan untuk menggambarkan hasil penelitian tetapi tidak digunakan untuk membuat kesimpulan yang lebih luas. Metode komparatif dalam penelitian ini adalah uji beda dua rata-rata sampel dependent (berpasangan) yang digunakan untuk mengetahui perbedaan pada variabel makro ekonomi yaitu tingkat inflasi, nilai tukar, penanaman modal asing, ekspor dan pertumbuhan ekonomi 1 tahun sebelum dan 1 tahun sesudah menerapkan kebijakan redenominasi mata uang pada negara yang sudah menerapkan kebijakan redenominasi mata uang. Pengambilan keputusan dalam uji beda dua rata-rata dilakukan dengan kriteria sebagai berikut:

a) Probabilitas signifikansi $>0,05$ maka $\mathrm{H}_{0}$ diterima atau tidak terdapat perbedaan antara variabel makro ekonomi sebelum dan sesudah redenominasi mata uang.

b) Probabilitas signifikansi $<0,05$ maka $\mathrm{H}_{0}$ ditolak atau terdapat perbedaan antara variabel makro ekonomi sebelum dan sesudah redenominasi mata uang.

c) $t_{\text {hitung }} \geq t_{\text {tabel }}$ maka $\mathrm{H}_{0}$ ditolak atau terdapat perbedaan makro ekonomi variabel makro ekonomi antara sebelum redenominasi mata uang dan sesudah redenominasi mata uang.

d) Jika nilai $t_{\text {hitung }} \leq t_{\text {tabel }}$ maka $\mathrm{H}_{0}$ diterima atau tidak terdapat perbedaan variabel makro ekonomi sebelum redenominani mata uang dan sesudah redenominasi mata uang.

Uji normalitas dibutuhkan sebelum melakukan uji statistik terhadap hipotesis untuk mengetahui apakah data-data yang ingin digunakan dalam penelitian berdistribusi normal atau tidak. Uji normalitas juga diperlukan untuk menentukan alat uji penelitian serta sebagai prasyarat dari uji beda dua rata-rata sampel yang berpasangan, dengan menggunakan uji nonparametric yaitu Kolmogorov-Smirnov dengan alat bantu IBM SPSS Statictics 20.

Pengambilan keputusan pada uji normalitas dilakukan dengan kriteria sebagai berikut:

a) Probabilitas signifikansi $>0,05$ maka hipotesis nol diterima yang berarti data terdistribusi secara normal.

b) Probabilitas signifikansi $<0,05$ maka hipotesis nol ditolak yang berarti data tidak terdistribusi secara normal.

a. Pilihan alat uji statistik atas hasil penelitian setelah dilakukan uji normalitas adalah:

c) Paired Sample T-Test bila data berdistribusi normal. 
d) Wilcoxon Signed Ranks Test bila data tidak berdistribusi normal.

\section{HASIL DAN PEMBAHASAN}

\section{Statistik Deskriptif}

Hasil uji statistik deskriptif menunjukkan nilai minimum, nilai maksimum, rata-rata, standar deviasi, dan peningkatan dari rata-rata variabel inflasi, nilai tukar, ekspor, penanaman modal asing, dan pertumbuhan ekonomi dari 20 negara sampel yang sudah menerapkan kebijakan redenominasi pada saat 1 tahun sebelum dan 1 tahun sesudah menerapkan kebijakan redenominasi mata uang yang disajikan pada Tabel 3.

Tabel 3. Deskriptif Statistik Variabel Penelitian

\begin{tabular}{lcccccc}
\hline Variabel & $\mathrm{N}$ & Rata-Rata & $\begin{array}{c}\text { Simpangan } \\
\text { Baku }\end{array}$ & Minimum & Maksimum & $\begin{array}{c}\text { Peningkatan } \\
\text { (Rata-Rata) }\end{array}$ \\
\hline Pretest Inflasi & 20 & 505.04 & 1424.01 & 8.50 & 6261.20 & -429.6 \\
Posstest Inflasi & 20 & 75.39 & 125.12 & -1.50 & 441.90 & \\
Pretest Nilai Tukar & 20 & 15.07 & 55.36 & .01 & 249.30 & 59.1 \\
Posstest Nilai Tukar 20 & 74.15 & 309.81 & .16 & 1390.00 & \\
Pretest Ekspor & 20 & 29.28 & 17.33 & 3.30 & 62.90 & 1.9 \\
Posstest Ekspor & 20 & 31.21 & 22.29 & 4.20 & 89.60 & \\
Pretest PMA & 20 & & & & 6443000000.0 & 1840341433 \\
& & 1590279014.25 & 1987505783.49 & -44350000.00 & 0 & \\
Posstest PMA & 20 & & & & 20185000000. & \\
& & 3430620447.20 & 5216565071.77 & -79000000.00 & 00 & \\
Pretest PE & 20 & 4.62 & 7.90 & -12.20 & 26.40 & 0.9 \\
Posstest PE & 20 & 5.47 & 5.76 & -4.30 & 25.00 & \\
\hline
\end{tabular}

Sumber :World Bank, diolah.

Pada Tabel 3 terlihat perubahan dari setiap rata-rata pada variabel makro ekonomi yang diteliti dalam penelitian ini pada 20 negara yang telah menerapkan redenominasi. Nilai peningkatan diketahui dari data rata-rata pretest variabel dikurang data rata-rata posttest variabel. Pada variabel inflasi terjadi penurunan rata-rata sebesar 429,6\% setelah menerapkan redenominasi, peningkatan angka pada rata-rata nilai tukar sebesar 59,1 yang artinya bahwa ratarata nilai tukar melemah sebesar 59,1 US\$ setelah redenominasi, peningkatan rata-rata ekspor sebesar 1,9\% setelah menerapkan redenominasi, terjadi peningkatan penanaman modal asing ratarata 1.840.341.433 US\$ dan peningkatan pertumbuhan ekonomi rata-rata sebesar 0,9\% setelah menerapkan redenominasi. Hasil pada uji statistik deskriptif digunakan untuk melihat gambaran data secara umum tetapi tidak digunakan sebagai jawaban hipotesis penelitian.

\section{Hasil Uji Normalitas}

Uji normalitas dilakukan untuk mengetahui apakah data-data yang ingin digunakan dalam penelitian berdistribusi normal atau tidak dan sebagai prasyarat sebelum melakukan uji beda dua rata-rata sampel berpasangan dengan menggunakan uji nonparametric yaitu Kolmogorov-Smirnov dengan alat bantu IBM SPSS Statictics 20. Hasil perhitungan uji normalitas disajikan pada Tabel 4. 
Tabel 4. Hasil Perhitungan Uji Normalitas Data Penelitian dengan Pendekatan KolmogorovSmirnov

\begin{tabular}{lcc}
\hline & & $\begin{array}{c}\text { Prob. } \\
\text { Nignifikansi }\end{array}$ \\
\hline Pretest inflasi & 20 & 0.001 \\
Posstest inflasi & 20 & 0.026 \\
Pretest nilai tukar & 20 & 0.000 \\
Posstest nilai tukar & 20 & 0.000 \\
Pretest ekspor & 20 & 0.445 \\
Posstest ekspor & 20 & 0.688 \\
Pretest PMA & 20 & 0.222 \\
Posstest PMA & 20 & 0.162 \\
Pretest PE & 20 & 0.592 \\
Posstest PE & 20 & 0.209 \\
\hline
\end{tabular}

Sumber: World Bank, diolah.

Berdasarkan hasil estimasi tersebut dapat diperoleh bahwa nilai sig data pretest dan posttest variabel inflasi dan nilai tukar adalah < 0,05 maka data penelitian prestest dan posttest untuk variabel inflasi dan nilai tukar tidak berdistribusi normal. Alat uji statistik yang digunakan untuk menguji hipotesis untuk variabel inflasi dan variabel nilai tukar adalah Wilcoxon Signed Rank Test. Sedangkan nilai sig data pretest dan posttest variabel ekspor, PMA dan pertumbuhan ekonomi adalah $>0,05$ maka data penelitian pretest dan posttest ekpor, PMA, dan pertumbuhan ekonomi berdistribusi normal sehingga alat uji statistik yang digunakan adalah uji beda Paired Sample T-Test.

\section{Hasil Uji Beda Dua Rata-Rata (Sampel Berpasangan)}

Uji beda dua rata-rata antara data pretest dan data posttest dari variabel inflasi, nilai tukar, ekspor, PMA, dan pertumbuhan ekonomi dilakukan untuk mengetahui ada tidaknya perbedaan pada variabel-variabe tersebut saat 1 tahun sebelum dan 1 tahun setelah menerapkan kebijakan redenominasi mata uang pada 20 negara yang telah menerapkan kebijakan redenominasi mata uang.

Berdasarkan hasil perhitungan pada Tabel 5 diperoleh bahwa nilai sig. inflasi 0,067 > 0,05 artinya tidak terdapat perbedaan sebelum dan sesudah penerapan redenominasi mata uang. Begitu juga dengan nilai sig untuk variabel ekspor, PMA, dan pertumbuhan ekonomi yaitu masing-masing 0,$360 ; 0,063 ; 0,311$ semuanya $>$ 0,05 artinya tidak terdapat perbedaan ekspor, PMA, dan pertumbuhan ekonomi sebelum dan sesudah penerapan redenominasi mata uang. Jika dilihat dari nilai thitung pada variabel ekspor, PMA, dan pertumbuhan ekonomi semuanya $<\mathrm{t}_{\text {tabel }}=2,093$ juga menunjukkan bahwa tidak terdapat perbedaan pada ketiga variabel tersebut saat sebelum dan sesudah penerapan redenominasi mata uang. Berdasarkan hasil perhitungan, perbedaan hanya terdapat pada nilai tukar dengan nilai sig $0,001<0,05$.

Tabel 5. Hasil Perhitungan Uji Beda Dua Rata-Rata

Data Pretest dan Data Posttest

\begin{tabular}{lccc}
\hline Variabel & Alat Uji Statistik & Prob. Sig. & Thitung \\
\hline Inflasi & Wilcoxon Signed Rank Test & 0,067 & - \\
Nilai Tukar & Wilcoxon Signed Rank Test & 0,001 & - \\
Ekspor & Paired Sample T-Test & 0,360 & 0,939 \\
PMA & Paired Sample T-Test & 0,063 & 1,973 \\
Pertumbuhan Ekonomi & Paired Sample T-Test & 0,311 & 1,041 \\
\hline
\end{tabular}

Sumber: World Bank, diolah.

Pada dasarnya, redenominasi mata uang tidak memiliki efek yang nyata pada makro ekonomi suatu negara, karena redenominasi merupakan kebijakan administrasi yang hanya menyangkut teknis penulisan mata uang atau sebagai langkah penyederhanaan nominal mata 
uang. Sesuai dengan hasil penelitian, perbedaan hanya terdapat pada variabel nilai tukar.Selebihnya, dengan atau tanpa kebijakan redenominasi tidak akan menimbulkan perbedaan keadaan inflasi, ekspor, PMA dan pertumbuhan ekonomi karena redenominasi hanyalah perubahan pada penulisan nominal mata uang yang tidak merubah nilai riil mata uang tersebut.Perbedaan keadaan nilai tukar setelah redenominasi yaitu negara yang telah menerapkan redenominasi mengalami depresiasi mata uang. Seperti terlihat pada Tabel 3 yang menunjukkan peningkatan pada rata-rata nilai tukar artinya adalah melemahnya nilai tukar setelah menerapkan redenominasi.

Jumlah uang beredar dalam jangka panjang mempunyai pengaruh signifikan terhadap perubahan nilai tukar rupiah terhadap dolar Amerika (Yuliyanti, 2014:291). Kebijakan redenominasi yang mengeluarkan uang baru akan meningkatkan JUB dan kecepatan beredarnya JUB yang menyebabkan tingkat harga dollar AS menjadi lebih tinggi atau nilai mata uang domestik terdepresiasi. Kondisi ini sesuai dengan teori penawaran uang karena antara uang beredar dan nilai tukar mempunyai hubungan positif (searah), bahwa kenaikan dalam penawaran uang domestik mengakibatkan mata uang domestik mengalami depresiasi.

Kondisi ekonomi yang baik setelah penerapan redenominasi pada suatu negara bergantung pada kondisi perekonomian sebelum negara tersebut menerapkan kebijakan redenominasi. Jika kondisi makro ekonomi suatu negara sedang dalam kondisi baik dan stabil maka setelah kebijakan redenominasi diterapkan, keadaan makro ekonomi suatu negara juga akan tetap dalam kondisi baik dan stabil, begitu juga sebaliknya. Kondisi makro ekonomi yang baik sebelum redenominasi diterapkan yaitu inflasi yang rendah bertipe creeping inflation atau sekitar satu digit setiap tahunnya, nilai tukar yang relatif stabil dan tidak mengalami depresiasi ataupun perubahan yang ekstrim dan fluktuatif, ekspor danpenanaman modal asing yang stabil atau pun meningkat, yang secara otomatis juga akan berdampak kepada pertumbuhan ekonomi.
Pengalaman beberapa negara yang telah menerapkan redenominasi mata uang dibutuhkan sebagai gambaran bagi Indonesia dalam mempersiapkan rencana redenominasi rupiah. Beberapa contoh negara yang sukses dalam melaksanakan kebijakan redenominasi adalah Turki, Polandia dan Romania. Negaranegara ini menerapkan redenominasi dengan memperhatikan kondisi ekonominya. Turki mempunyai pengalaman mirip rencana redenominasi di Indonesia yaitu adanya kebijakan redenominsasi bukan karena negara sedang mengalami hyper inflation melainkan untuk penyederhanaan nominal pada mata uang.Syarat sukses redenominasi Turkiadalah keharusan negara pelaku redenominasi melakukan stabilisasi harga dan mendorong pertumbuhan ekonomi. Di Polandia, penyederhanaan nilai mata uang dilakukan setelah seluruh program stabilisasi telah diteliti.Polandia dianggap telah melaksanakan proses restrukturisasi perekonomian secara besarbesaran, dan melakukan upaya liberalisasi. Dua hal inilah yang dianggap telah sukses menghantarkan reformasi nilai tukar Polandia. Tahun 2000 Rumania mampu menstabilkan ekonomi makronya dengan ciriciri: pertumbuhan ekonomi tinggi dan tingkat pengangguran rendah.Setelah redenominasi, nilai tukar mata uang Rumania menguat, terhadap dolar AS menjadi 2,81 Lei.Sebagai perbandingan, sebelum redenominasi, 30 Juni 2005, nilai tukar terhadap US\$ sebesar 3,26 Lei.

Argentina, Brasil dan Rusia tercatat sebagai negara-negara yang gagal dalam melakukan redenominasi mata uang.Kebutuhan Argentina dan Brasil dalam menghilangkan beberapa angka nol di mata uangnya muncul setelah reddenominasi beberapa kali dilaksanakan.Kombinasi sukses memangkas inflasi dan masuknya modal asing yang meningkatkan cadangan devisa merupakan faktor terpenting keberhasilan redenominasi di Brasil dan Argentina.Kegagalan redenominasi di Argentina dan Brasil diakibatkan kebijakan redenominasi dilaksanakan ketika terjadi pelemahan dan ekonomi tak siap. Satu tahun sebelum penerapan redenominasi, inflasi di dua 
negara ini tergolong tinggi yaitu 133 persen pada tahun 1992 di Argentina dan 2001,3 persen pada tahun 1994 di Brasil, sehinggal kondisi tersebut dinilai tidak siap untuk menerapkan redenominasi.Pemerintah Brasil dan Argentina tidak mampu mengelola inflasi yang sangat tinggi. Contoh negara lainnya yang tergolong gagal dalam menerapkan redenominasi adalah Rusia.Pada pertengahan upaya redenominasi, pemerintah gagal mengelola obligasi yang terus menggunung.

Indonesia saat ini sedang mengalami kondisi perekonomian yang kurang stabil untuk menerapkan kebiakan redenominasi rupiah. $\mathrm{Hal}$ ini ditandai dengan nilai tukar rupiah yang hingga saat ini pergerakannya masih sangat fluktuatif, terapresiasi dan terdepresiasi secara bergantian. Selama enam bulan pertama tahun 2015 cenderung terdepresiasi 5-6\%. Namun inflasi di Indonesia tidak tergolong hyper inflation. Dalam semester I 2015, inflasi hanya 0,96. Penurunan daya beli masyarakat sebesar 7\% pada semester I tahun 2015 berdampak pada menurunnya pertumbuhan ekonomi dan ekspor Indonesia. Penurunan pertumbuhan ekonomi dari target diatas 5\% menjadi 4,7\%. Indonesia akan lebih baik jika melaksanakan redenominasi ketika situasi ekonomi Indonesia sudah baik dan stabil daripada ketika kondisi ekonomi di Indonesia masih kurang stabil seperti saat ini dengan tujuan agar keadaan ekonomi pasca redenominasi juga baik dan stabil.

\section{SIMPULAN}

Berdasarkan hasil penelitian dan pembahasandapat diambil kesimpulan bahwa tidak terdapat perbedaan pada variabel inflasi, ekspor, PMA, dan pertumbuhan ekonomi sebelum dan sesudah redenominasi. Perbedaan sebelum dan sesudah menerapkan redenominasi mata uangterdapat pada variabel nilai tukar yaitu nilai tukar semakin lemah setelah penerapan redenominasi mata uang.Saran yang dapat diberikan dari penelitian ini adalah dengan memperbaiki kondisi makro ekonomi Indonesia sebelum menerapkan redenominasi rupiah dengan mempertahankan tingkat inflasi di Indonesia agar tetap bertipe creeping inflation, menstabilkan nilai tukar rupiah, meningkatkan ekspor di Indonesia, meningkatkan penanaman modal asing di Indonesia serta memastikan pertumbuhan ekonomi relatif meningkat sebelum menerapkan rencana redenominasi rupiah.

\section{DAFTAR PUSTAKA}

Alhusain, A.S. 2012. Rencana Redenominasi Rupiah. Info Singkat Ekonomi dan Kebijakan Publik.Vol.IV, No.24. Jakarta: P3DI Setjen DPR RI.

Dogarawa, A.B. 2007. The Economics of Currency Redenomination: An Appraisal of $\mathrm{CBN}$ Redenomination Proposal. MPRA Paper No. $23195 . \quad$ http://mpra.ub.unimuenchen.de/23195/ (diakses 08 April 2015).

Iona.Duca. 2005. The National Currency Redenomination Experience in Several Countries, A Comparative Analysis. http://ssrn.com/abstract $=1347407$ (diakses 04 Desember 2014).

Lianto, Johan dan Ronald Suryaputra. 2012. The Impact of Redenomination in Indonesia from Indonesian Citizens' Perspective. ProcediaSocial and Behavioral Sciences.www.sciencedirect.com (diakses 04 Desember 2014).

Moesly, Layna. 2005. Dropping Zeros, Gaining Credibility? Currency Redenomination in Developing Nations.Annual Meeting of the American Political Science Assosiation. Washington, DC.

Nababan, Sihol. 2011. Redenominasi Mata Uang: Isu Panas bagi Rupiah. Vol. II No. 1. Medan: FEUHN.

Nurrohim, M. (2013). Analisis Kausalitas Volatilitas Nilai Tukar Mata Uang dengan Kinerja Sektor Keuangan dan Sektor Rill. Economics Development Analysis Journal, 2(4).

Pambudi, Andika dkk. 2014. Penentu Keberhasilan $1 Q$ Redenominasi Mata Uang: Pendekatan Historis dan Eksperimental. Buletin Ekonomi Moneter dan Perbankan, Vol. 17 No. 2. Bogor: Departemen Ilmu Ekonomi IPB

Prasad, R.A.E.S. \& Zhang, , 2015. What Measure Of Inflation Should A Developing Country Central Bank Target? Journal of Monetary Economics, 74, pp.102-16.

Suhendra, E dan S.W. Handayani. 2012. Impacts of Redenomination on Eonomics Indicators.International Conference on Eurasian Economics. 
Ulfa, S. (2012). Pengaruh Jumlah Uang Beredar (Jub), Suku Bunga Sertifikat Bank Indonesia (Sbi), Impor, Ekspor Terhadap Kurs Rupiah/ Dollar Amerika Serikat Periode Januari 2006 Sampai Maret 2010. Economics Development Analysis Journal, 1(1).

Yuliyanti, I. (2014). Pengaruh Jumlah Uang Beredar (M2), Tingkat Suku Bunga Sbi, Impor, Dan Cadangan Devisa Terhadap Nilai Tukar Rupiah / Dolar Amerika Tahun 2001 . 2013. Economics Development Analysis Journal, 3(2). http://data.worldbank.org

Zhao, L. \& Li, L., 2015. Interest Rate, Money Demand And Seigniorage: The Chinese Hyperinflation 1946-1949. China Economic Review, 34, pp.169179. 